\title{
Association experiment in practice of linguistic and cultural dominants research
}

\author{
Svetlana Takhtarova ${ }^{1}$, Diana Sabirova ${ }^{2}$ \\ ${ }^{1}$ Dept of Theory and Practice of Translation, Kazan Federal University, Russia \\ ${ }^{2}$ Dept of European Languages and Cultures, Kazan Federal University, Russia \\ https://doi.org/10.36505/ExLing-2016/07/0041/000300
}

\begin{abstract}
The paper is devoted to experimental definition of the changes happening in structure of cultural dominants of the German ethnosociety on the example of a linguistic and cultural concept of Ordnung. To provide well-grounded conclusions on the status of the problem and determine the axiological characteristics of the concept the authors carried out an associative experiment. The respondents were asked to write several words to the given words incentives. The experiment confirms that cultural constants are dynamic formations which bound to change. The changes characteristic of Ordnung as a cultural dominant inevitably involve modification of the German communicative style that is shown, in particular, in greater tolerance to deviations from norms and standards, smaller degree of criticality and straightforwardness.
\end{abstract}

Key words: associative experiment, concept, cultural dominants.

\section{Introduction}

Cultural concepts, representing the most important category of cultural linguistics, are actively studied as exemplified in the material of different languages and cultures. The main characteristic of linguocultural concept is, as it is well known, its value component (Karasik 2004). The culture dominants, most important concepts for a given culture, constitute the core value of worldview peculiar to a specific culture.

The Ordnung concept, which is the subject of this article, traditionally considered as one of the key cultural landmarks of the German ethnosociety (Bartminsky 2005, Medvedev 2007, Ter-Minasova 2007, Markowsky 1995, Matussek 2006). Vezhbitska notes that Germans should have Ordnung (order) and live in a world where Ordnung "reigns". In fact, only Ordnungcan guarantee their inner peace (Wierzbicka 1999). According to Bauzinger untranslatability of German words Ordnungsamt, Ordnungswidrigkeit, Ordnungsstrafe, ordnungspolitische Massnahme proves the order concept to be of idioethnic character in German society. In this context the order is not only a social principle, limiting every single person to a particular behavioral pattern or framework, but also a norm, which every person adheres to without any coercion (Bausinger 2002).

ExLing 2016: Proceedings of $7^{\text {th }}$ Tutorial and Research Workshop on Experimental Linguistics, 27 June - 2 July 2016, Saint Petersburg, Russia 
At the same time, the cultural dominants, despite its rigidity, can change over time, similarly to the way the culture and the society evolve.

\section{Materials and Methods}

We conducted an open associative experiment to identify how the Ordnung concept is understood in modern German society and to determine its axiological characteristics. The experiment features 120 informants that we provisionally divided into three age groups: young people and students (20-27 years old), employed respondents (28-60 years) and senior citizens. During the experiment, respondents were asked to write a few words they associate with the word-stimulus Ordnung. Besides association questionnaire respondents were offered evaluation questionnaire, in which they had to indicate their attitude to the word-stimulus as "+" - positive, "-" - negative or "0" - indifferent. Thus, the purpose of the experiment, which involves determining the value component of the concept under consideration, both explicitly, through informant directly evaluating the given concept, but also implicitly, through the analysis of obtained during the experiment associations to a given word-stimulus.

\section{Results}

The conducted experiment has allowed to define the following features of Ordnung concept.

Firstly, most responses given by elderly people, i.e. third age group, constituting associations they have given to the word-stimulus represent axiomatic phrases and clichés: Ordnung muss sein (31\%) and Ordnungist das balbe Leben (26\%). It is indicative, in our view, that such phrases appear only sporadically in the responses of informants representing the first and the second group.

Secondly, such verbal responses aswichtig, notwendig, sehrwichtig, sehrpositiv were given by the representative of the third group, thus, confirming normative-evaluative nature of the analyzed concept. The responses of the informants comprising the first and the second group are way less "axiological" - 4\% and 12\%, respectively. Moreover, verbal responses submitted by youth group respondents reflect not only the positive but also the negative perception of the stimulus-word: einschränkend, überscbätə̧t, bremst Kreation, Druck, nichtimmer. In general, negative associations are insignificant (16\%), but their presence in the responses of young respondents is, in our opinion, of symptomatic character. 
Thirdly, many informants of the youth group associate Ordnung with purity and establishing order, which is evidenced by the following, rather frequent responses: Sauberkeit, Sauber, Aufräumen, Zimmer. Similar words are given by the representatives of the second age group, although much less frequently. For the older generation the order is associated primarily with the "mental" order and structured and well-organized life: Gedanken, Sicherheit im Leben. Confirmation that is The fact that in many questionnaires informants of this group provided not only single words as responses to the word-stimulus, but detailed answers confirm the idea that Ordnungis perceived by the oldest age group as an immutable value.

Ich liebe sie, weil sie das eigene Leben und das der anderen erleichtert; sie sollte anzustreben sein, um besser zuleben; notwendig, um in eigener Umweltbestehen zu können.

Fourthly, the associations of the youth group have been more varied and diverse in terms of semantics. Thus, in particular, the responses of this group contain following words, which are absent in the response given by the other two groups of informants: Hierarchie, Gleichmäßigkeit, Planung, Organisation, Recht, Organisiertheit, Struktur, Kalender, Eltern. The last word-response is probably due to the fact that the order is instilled by parents and children education begins, first of all, with meeting their own room cleanness requirements. Thereby, the associations are closely connected with the above-named frequent responses given by the representatives of the group, denoting the cleaning and order. Connection with the cleaning procedure is peculiar to responses of the informants from the second group, evidenced by the following associations: Putzfrau, Schreibtisch, Zimmer, Schrank.

It is noteworthy that unlike antonymy synonymy is not relevant element in the responses of all three groups of respondents. Antonymous verbal responses like Chaos, Unordnung were registered only sporadically.

Thus, the concept of Ordnung, remaining the culture dominant is undergoing some changes in its content and value components. In particular, it can be argued that for the younger generation, this concept has a more utilitarian, practical significance. Associations given by the representatives of student-youth groups have far fewer positive words, which indicates a change in the axiological component of the analyzed concept. Proof of this are the results of the axiological survey, which are, in our opinion, very significant in this respect. In particular, it was found that for the vast majority of informants of the oldest group Ordnung concept has positive connotation - $98 \%$ of respondents demonstrated their positive attitude towards this concept. 
Answers of the second group are not so unambiguous - 56\% defined their attitude to the order as positive and $44 \%$ as neutral.

Attitude of informants from the youth group to the Ordnung concept proved to be most ambivalent: positive attitude to the order shown by $48 \%$ of the respondents, neutral $-44 \% .8 \%$ of informants in this group defined their attitude towards this concept as a negative.

\section{Conclusions}

The conducted experiment allows for a conclusion that cultural constants represent dynamic formations, content of which may change reflecting alterations in the systems of values specific to a particular ethnosociety. In this context, the study dedicated to the study of the value component of lingocultural concepts is of particular importance, as the results of such studies are relevant for establishing and sustaining effective cross-cultural communication.

\section{References}

Karasik, V.I. 2004. Language Circle: Personality, Concepts, Discourse. Moscow, Gnozis.

Bartmin'skiy, Ye. 2005. Language imageofthe World: Essays on Ethnolinguistics. Moscow, Indrik.

Medvedeva, T.S. 2007. Representation of Ordnungconcept in German linguistic picture of the world. Herald of Udmurskiy University. Philology, 5(2).

Ter-Minasova, S.G. 2007. War and Peace of Languages and Cultures: Theory and Pracitice. Moscow, Astrel': Khranitel'.

Markowsky, R. 1995. Studienhalber in Deutschland: interkulturelles Orientierungstraining für amerikanische Studenten, Schüler und Praktikanten. Heidelberg, Asanger.

Matussek, M. 2006. Wir Deutschen. Warum uns die anderen gern haben können. Frankfurt /Main, S. Fischer Verlag

Wierzbicka, A. 1999. Semantic Universals and Language Description. Moscow, Yazyki Russkoy Kul'tury.

Bausinger, H. 2002. Typisch deutsch. Wie deutsch sind die Deutschen? München, Beck HG - Verlag. 